\title{
RESEARCH
}

Open Access

\section{Description of trauma among French service members in the Department of Defense Trauma Registry: understanding the nature of trauma and the care provided}

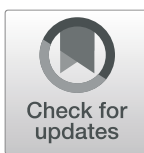

Marc A. Schweizer ${ }^{1 *}$ (D) Jud C. Janak', Zsolt T. Stockinger ${ }^{2}$ and Tristan Monchal ${ }^{3}$

\begin{abstract}
Background: Since 2001, the French Armed Forces have sustained many casualties during the Global War on Terror; however, even today, there is no French Military trauma registry. Some French service members (SMs) were treated in US Military Medical Treatment Facilities (MTFs) and were recorded in the US Department of Defense Trauma Registry (DoDTR). Our objective was to conduct a descriptive analysis of the injuries sustained by French SMs reported in the DoDTR and subsequent care provided to them to assist in understanding the importance of building a French Military trauma registry.
\end{abstract}

Methods: Using DoDTR data collected from 2001 to 2017, a retrospective descriptive analysis was conducted. We identified 59 French SMs treated in US MTFs. The characteristics of the SMs' demographics, injuries, care provided to them, and discharge outcomes were summarized.

Results: Among the 59 French SMs identified, 46 (78\%) sustained battle injuries (Bls) and 13 (22\%) sustained nonbattle injuries (NBIs). There were 47 (80\%) SMs injured in Afghanistan (Opération Pamir), while 12 (20\%) were injured in Opération Chammal in Iraq and Syria. Explosives accounted for 52.5\% of injuries, while $25.4 \%$ were due to gunshot wounds; all were Bls. The majority of reported injuries were penetrating (59.3\%), most of which were Bls (71.7\%). The mean Injury Severity Score for Bls was $12(S D=8.9)$ compared to $6(S D=1.7)$ for NBls. Around half of SMs $(n=30 ; 51 \%)$ were injured in Afghanistan between the years 2008-2010. Among a total of 246 injuries sustained by 59 patients, extremities were the body part most prone to Bls followed by the head and face. Four SMs died after admission (6.8\%). Conclusions: The DoDTR provides extensive data on trauma injuries that can be used to inform injury prevention and clinical care. The majority of injuries sustained by French SMs were Bls, caused by explosives, and predominantly occurring to the extremities; these findings are similar to those of other studies conducted in combat zones. There is a need to establish a French Military trauma registry to improve the combat casualty care provided to French SMs, and its creation may benefit from the DoDTR model.

Keywords: French service members, U.S. military treatment facility, Trauma registry

\footnotetext{
* Correspondence: marc.a.schweizer2.ctr@mail.mil

${ }^{1}$ United States Department of Defense Joint Trauma System, Joint Base San

Antonio Fort Sam Houston, Houston, TX 78234, USA

Full list of author information is available at the end of the article
}

(c) The Author(s). 2019 Open Access This article is distributed under the terms of the Creative Commons Attribution 4.0 International License (http://creativecommons.org/licenses/by/4.0/), which permits unrestricted use, distribution, and reproduction in any medium, provided you give appropriate credit to the original author(s) and the source, provide a link to the Creative Commons license, and indicate if changes were made. The Creative Commons Public Domain Dedication waiver (http://creativecommons.org/publicdomain/zero/1.0/) applies to the data made available in this article, unless otherwise stated. 


\section{Introduction}

Since the start of the Global War on Terror in 2001, French military forces have been part of the international military coalitions' forces in different operations in Afghanistan and the Middle East (i.e. Iraq and Syria). From 2001 to 2014, France was involved in Opération Pamir as a part of the International Security and Assistance Force (ISAF) in Afghanistan led by the North Atlantic Treaty Organization (NATO), which ran concurrently with its US counterpart, Operation Enduring Freedom (OEF) that began in October $2001[1,2]$. Within the ISAF, the French forces participated under Opération Héraclès and Opération Arès. French forces were also involved in Opération Epidote that aimed to provide training and support to the Afghan Army. France assumed command of the medical hospital at the Kabul International Airport (KaIA) located in the capital region of Afghanistan from 2009 to 2014 [3]. This NATO hospital provided Role 3 medical and surgical capability care to Coalition and Afghan patients [4]. From 2014 onward, France became involved in the international coalition against terrorism in Iraq and Syria in Opération Chammal alongside the American counterpart Operation Inherent Resolve (OIR).

The conflicts associated with the Global War on Terror were and continue to be responsible for a significant number of combat-related injuries among coalition military forces, including French service members (SMs) [5]. The French Military Center for Epidemiology and Public Health (Centre d'Epidémiologie et de Santé Publique des Armées) collects all ballistic and explosive injury data from weekly healthcare reports provided by deployed French military treatment facilities (MTFs). However, these reports tend to be selective, heterogeneous, and reporter-dependent [6]. Since 2003, the French Military Health Service (Service de Santé des Armées) [7] has managed an electronic database that contains a prospective surgical record of procedures performed by deployed surgeons at Role 2 (Forward Surgical Teams that provide primary care and basic emergency treatment) and Role 3 (Combat Support Hospitals that provide the highest level of medical care in combat zones) levels. This registry was the source of several studies that focused on the surgical workload of French MTFs (e.g., Bonnet et al., 2012 [5]; Barbier et al., 2014 [3]; Malgras et al., 2016 [8]; de Lesquen et al., 2016 [9]; Beranger et al., 2017 [10]; Barbier et al., 2017 [11]).

Since 2001, the United States Department of Defense Trauma Registry (DoDTR), formerly the Joint Theater Trauma Registry (JTTR), has collected data on traumatic injuries sustained by any patient treated in US MTFs as well as information regarding patient demographics and care provided $[12,13]$. Those treated in these MTFs can be US SMs, their beneficiaries, non-US coalition SMs, host nation security forces, and local civilians. The DoDTR is the largest military medical trauma database in existence. It provides crucial evidence necessary to support clinical research and performance improvements throughout military medicine and contributes to medical advances in combat casualty care. To our knowledge, there are no studies regarding French SMs treated in US MTFs, and there is a knowledge gap in regard to their experiences before being discharged or transferred to French MTFs. The French Military may potentially benefit from a descriptive summary of injury pattern of these casualties. Moreover, such a summary would illustrate the importance of the multinational nature of medical support that is now part of modern operations. The objective of this study was to describe the injuries sustained by French SMs treated in US MTFs and subsequent care provided to them in order to understand the importance of creating a French Military trauma registry based on the JTS DoDTR model.

\section{Methods}

Using data from the DoDTR that was collected from 2001 to 2017, we conducted a retrospective descriptive analysis. The DoDTR is a US military trauma registry that is maintained by the Joint Trauma System (JTS) [14] and contains data from abstracted medical records of patients who sustained traumatic injuries and were treated in US MTFs. There were two primary inclusion criteria for this analysis, as follows: (1) French SMs who sustained traumatic injuries and (2) treatment must have occurred in at least one US MTF, regardless of location, cause of injury, or the operation in which they were involved. We intended to examine the traumatic injuries in deployed settings; therefore, French civilians were excluded from this study. The patients who were included were stratified into two groups based on whether the injuries sustained had occurred in battle or nonbattle settings.

For each group (i.e., battle vs. nonbattle), we conducted a descriptive summary of patient demographics, injury characteristics (e.g., injured body region, injury severity, etc.), and medical interventions (e.g., type of procedures done, type and amount of resuscitative fluids and blood products given). We plotted the injuries per year in order to provide a visualization of injury trends. We used the Abbreviated Injury Scale (AIS) to identify injured body regions and to calculate the overall Injury Severity Score (ISS) [15]. When describing categorical variables, we reported the total number and percent stratified by battle status, while for continuous variables, the mean and the standard deviation (SD) were reported. Chi-square tests were used for categorical variables, while Student's $t$-tests were used for continuous variables. A $p$-value of 0.05 was used to define statistical significance. The injuries sustained per body region were plotted against their severity to provide a better understanding of which body region 
sustained more severe injuries in this particular population. We also looked into some of these characteristics per MTF Role in order to examine the characteristics of the injuries and the care provided by the MTFs' perspective. We defined prehospital transportation time as the time difference in minutes between reported injury time and arrival time to the first US MTF, as reported in the DoDTR. We used $\mathrm{SAS}^{\circ}$ version 9.4 $\left(\mathrm{SAS}^{\circ}\right.$ Institute Inc., Cary, NC) to conduct our analyses. This quality improvement project was deemed exempt from institutional board review by the US Army Institute of Surgical Research because it was not designed to contribute to generalizable knowledge, and therefore, it did not constitute research as defined in 32 CFR 219.102(d).

\section{Results}

There were 59 French SMs who sustained traumatic injuries and were treated in US MTFs, of these, 46 (78\%) were battle injuries (BIs) and $13(22 \%)$ were nonbattle injuries (NBIs) (Table 1). The mean age was 30.6 years

Table 1 Demographic characteristics of French service members treated in US Military Medical Treatment Facilities

\begin{tabular}{|c|c|c|c|c|}
\hline Characteristics & $\begin{array}{l}\text { Battle } \\
n=46(78 \%)\end{array}$ & $\begin{array}{l}\text { Non-Battle } \\
n=13(22 \%)\end{array}$ & $\begin{array}{l}\text { Total } \\
n=59\end{array}$ & $p$-value \\
\hline$\overline{\mathrm{Age}^{\mathrm{a}}}$ & & & & 0.08 \\
\hline $19-24$ & $12(26.1 \%)$ & - & $12(20.3 \%)$ & \\
\hline $25-29$ & $12(26.1 \%)$ & $5(38.4 \%)$ & $17(28.8 \%)$ & \\
\hline $30-34$ & $11(23.9 \%)$ & $2(15.4 \%)$ & $13(22 \%)$ & \\
\hline $35-39$ & $3(6.5 \%)$ & $2(15.4 \%)$ & $5(8.5 \%)$ & \\
\hline $40-48$ & $4(8.7 \%)$ & $4(30.8 \%)$ & $8(13.6 \%)$ & \\
\hline Unknown & $4(8.7 \%)$ & - & $4(6.8 \%)$ & \\
\hline Mean $\pm S D^{b}$ & $29.1 \pm 6.9$ & $35.5 \pm 8.0$ & $30.6 \pm 7.6$ & \\
\hline Gender & & & & - \\
\hline Male & $46(100 \%)$ & $13(100 \%)$ & 59 (100\%) & \\
\hline Female & - & - & - & \\
\hline Military Operation & & & & 0.29 \\
\hline $\mathrm{OEF}^{\mathrm{C}}$ & $38(82.6 \%)$ & $9(69.2 \%)$ & 47 (79.7\%) & \\
\hline$O R^{d}$ & $8(17.4 \%)$ & $4(30.8 \%)$ & $12(20.3 \%)$ & \\
\hline Mechanism of Injury & & & & $<0.01$ \\
\hline Explosive & $31(67.4 \%)$ & - & $31(52.5 \%)$ & \\
\hline Gunshot wound & 15 (32.6\%) & - & 15 (25.4\%) & \\
\hline Crush & - & $1(7.7 \%)$ & $1(1.7 \%)$ & \\
\hline Fall & - & $2(15.4 \%)$ & $2(3.4 \%)$ & \\
\hline Fire/Flame & - & $1(7.7 \%)$ & $1(1.7 \%)$ & \\
\hline Helicopter crash & - & $2(15.4 \%)$ & $2(3.4 \%)$ & \\
\hline Knife/Sharp object & - & $2(15.4 \%)$ & $2(3.4 \%)$ & \\
\hline Motor Vehicle Crash & - & $5(38.4 \%)$ & $5(8.5 \%)$ & \\
\hline Predominant Injury Type & & & & $<0.01$ \\
\hline Penetrating & $33(71.7 \%)$ & $2(15.4 \%)$ & $35(59.3 \%)$ & \\
\hline Blunt & $7(15.2 \%)$ & $10(76.9 \%)$ & $17(28.8 \%)$ & \\
\hline Burn & $6(13.1 \%)$ & $1(7.7 \%)$ & $7(11.9 \%)$ & \\
\hline Injury Severity Score & & & & 0.29 \\
\hline $1-8$ & $20(43.5 \%)$ & $9(69.2 \%)$ & 29 (49.1\%) & \\
\hline $9-15$ & $12(26.1 \%)$ & $3(23.1 \%)$ & $15(25.4 \%)$ & \\
\hline $16-25$ & $8(17.4 \%)$ & $1(7.7 \%)$ & $9(15.3 \%)$ & \\
\hline$>25$ & $6(13 \%)$ & - & $6(10.2 \%)$ & \\
\hline Mean $\pm S D^{b}$ & $12 \pm 8.9$ & $5.8 \pm 1.7$ & $10.6 \pm 8.0$ & \\
\hline
\end{tabular}

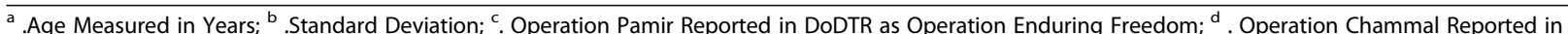
DoDTR as Operation Inherence Resolve 
Table 2 Injuries' Counts among French Service Members Treated in US Military Medical Treatment Facilities Stratified by Body Region and Injury Classification (Battle vs. Nonbattle)

\begin{tabular}{|c|c|c|c|c|}
\hline Body Region & $\begin{array}{l}\text { Battle Injuries } \\
n=217 \text { (88\%) }\end{array}$ & $\begin{array}{l}\text { Nonbattle Injuries } \\
n=29(12 \%)\end{array}$ & $\begin{array}{l}\text { Total Injuries } \\
n=246\end{array}$ & $p$-value \\
\hline Head & $30(13.8 \%)$ & $6(20.7 \%)$ & $36(14.6 \%)$ & 0.34 \\
\hline Face & $21(9.7 \%)$ & $4(13.8 \%)$ & $25(10.2 \%)$ & 0.53 \\
\hline Neck & $1(0.5 \%)$ & - & $1(0.4 \%)$ & 1.00 \\
\hline Thorax & $30(13.8 \%)$ & $2(6.9 \%)$ & $32(13.0 \%)$ & 0.39 \\
\hline Abdomen & $26(12.0 \%)$ & $3(10.3 \%)$ & $29(11.8 \%)$ & 1.00 \\
\hline Spine & $6(2.7 \%)$ & $3(10.3 \%)$ & $9(3.7 \%)$ & 0.08 \\
\hline Extremities & $73(33.6 \%)$ & 7 (24.2\%) & $80(32.5 \%)$ & 0.21 \\
\hline Upper Extremities & $32(14.7 \%)$ & $4(13.8 \%)$ & $36(14.6 \%)$ & 0.78 \\
\hline Lower Extremities & 41 (18.9\%) & $3(10.3 \%)$ & $44(17.9 \%)$ & 0.31 \\
\hline External or Burn & $29(13.4 \%)$ & $4(13.8 \%)$ & $33(13.4 \%)$ & 1.00 \\
\hline Unknown & $1(0.5 \%)$ & - & $1(0.4 \%)$ & 1.00 \\
\hline
\end{tabular}

$(\mathrm{SD}=7.6)$; those with BIs were on average 29.1 years old $(\mathrm{SD}=6.9)$ compared to 35.5 years $(\mathrm{SD}=8)$ for those with NBIs. All of the 59 injured SMs were male. There were 47 (80\%) French SMs injured in Opération Pamir (reported in the DoDTR as Operation Enduring Freedom), while $12(20 \%)$ were injured in Opération Chammal (reported as Operation Inherent Resolve). More than half of all injuries were caused by explosives (52.5\%), while a quarter (25.4\%) were due to gunshots; all of these causes were battle-related. NBIs consisted of crushing, falls, fires or flames, helicopter crashes, motor vehicle crashes, and sharp objects.

BIs accounted for $88 \%$ of all injuries (217 of 246) with an average of 5 injuries per person, while NBIs $(n=29)$ were approximately $12 \%$ of all injuries with an average of 2 injuries per person (Table 2). Around one-quarter of all injuries (25.4\%) happened in 2009, while the fewest occurred in 2007 and 2014 (1.7\% each). All of the injuries in the aforementioned years were in battle settings (Fig. 1). More than half of all SMs $(n=30 ; 51 \%)$ were injured during the years 2008-2010, with only three (5.1\%) occurring in nonbattle settings. Most reported injuries were penetrating in nature $(59.3 \%)$, of which the majority were in battle settings $(71.7 \%$; $p$-value: $<0.01)$. The overall mean Injury Severity Score (ISS) was 10.6 $(\mathrm{SD}=8)$, with around half of all SMs sustaining minor injuries with an ISS of $1-8(49.1 \%)$. The mean ISS for BIs was $12(\mathrm{SD}=8.9)$ compared to $5.8(\mathrm{SD}=1.7)$ for

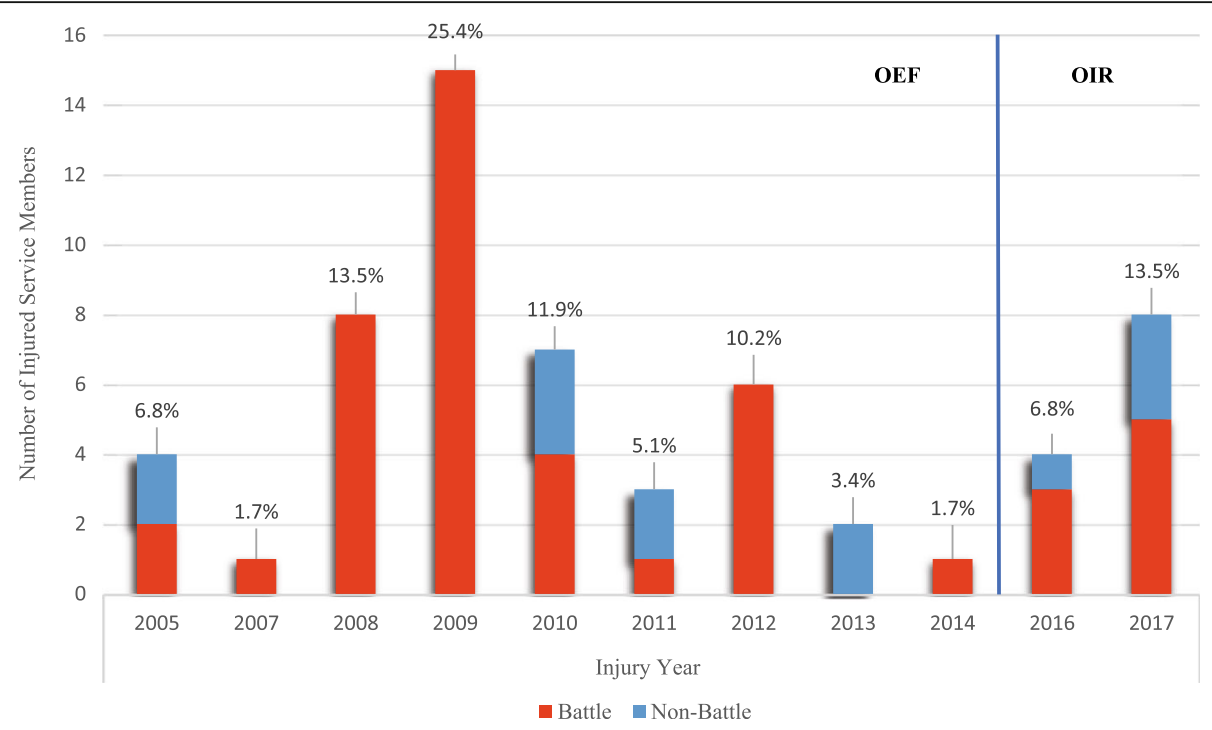

Fig. 1 Counts and Percentages of French Service Members Treated in US Military Treatment Facilities (2005-2017). OER Operation Enduring Freedom, OIR Operation Inherent Resolve 
NBIs (Table 1). Extremities were the body part most prone to BIs (32.5\%), followed by the head and face (24.8\%; Table 2). There was no significant difference in body region distribution between BIs and NBIs. The head received a higher proportion of severe injuries $($ AIS $\geq 4$ ) than other body regions (Fig. 2).

There were a total of 74 admissions to US MTFs along the continuum of care: 12 SMs to Role 2, 54 to Role 3, and 8 to Landstuhl Regional Medical Center Role 4 in Germany. The mean prehospital transportation time was $223.9 \mathrm{~min}$ (SD: 284.6): $153.9 \mathrm{~min}$ in Afghanistan (SD: 321.9) and $328.8 \mathrm{~min}$ during Operation Inherent Resolve (SD: 185.7). However, injury time and arrival time were only available in $42.4 \%$ of the records ( 25 patients). The most frequent transportation method to the 1st facility was by helicopter, used in $61 \%$ of patients, followed by ground transport in $7 \%$, while $32 \%$ were unknown. Only 9 patients had records of tourniquets (15.3\%), with a total of 21 tourniquets placed. At the first admission of the 59 patients, $8.6 \%$ were hypothermic $\left(\leq 96.8^{\circ} \mathrm{F}\right.$ or $\left.36^{\circ} \mathrm{C}\right)$ out of 43 available records, $5.6 \%$ had a systolic blood pressure $<90 \mathrm{mmHg}$ out of 54 available, $9.8 \%$ had an oxygen saturation $<90 \%$ out of 51 available, $11.8 \%$ had a Glasgow Coma Scale $<13$ out of 51 available, and $16.3 \%$ had a pulse rate higher than 120 out of 53 available records.

There were 29 diagnostic ultrasonography exams of the abdomen recorded in the registry and 113 computed tomography tests (CT scans), including 32 head, 25 chest, 26 abdominopelvic, and 30 unspecified CT scans. Table 3 provides a detailed summary of the procedures reported per specialty and MTF Role. A total of 173 surgical procedures were recorded in the DoDTR, most of which were performed in Role 3 MTFs $(n=143 ; 83.0 \%)$. The most common surgical procedures involved soft tissue and included debridement, suturing, and dressing (39.9\%), followed by orthopedic (19.7\%), and abdomen procedures (16.7\%). Resuscitative fluids were given to 26 French SMs (44.1\%), with an average of 4.11 of fluid per patient; 22 of these patients had BIs. Fourteen patients required blood products (23.7\%); 12 of them sustained injuries in battle settings, and those patients received, on average, 25 units of blood. There was no significant difference in the fluids or blood products given to patients with BIs and NBIs (Table 4). In regard to the destinations of the French SMs after the Emergency Department, $46 \%$ were admitted to operating rooms (ORs), $47 \%$ to Intensive Care Units (ICUs), and 29\% were admitted to both the OR and ICU (Fig. 3). The overall length of stay for most French SMs in US MTFs was short: less than $24 \mathrm{~h}$ in Role 2 and around one day in Role 3 and Role 4. In regard to the final discharge status reported in the DoDTR, approximately $60 \%$ of patients were transferred to other MTFs, either French $(n=22 ; 37.3 \%)$, American $(n=9$; $15.2 \%)$, or local MTFs $(n=4 ; 6.8 \%)$. There were 19 SMs (32.2\%) who returned to duty, one discharged to home (1.7\%), and 4 SMs died of their wounds (6.8\%): 3 in Role 3 MTFs and one in a Role 4 MTF (Table 5).

\section{Discussion}

Casualties of the Global War on Terror continue to occur in many areas in the world where the NATO

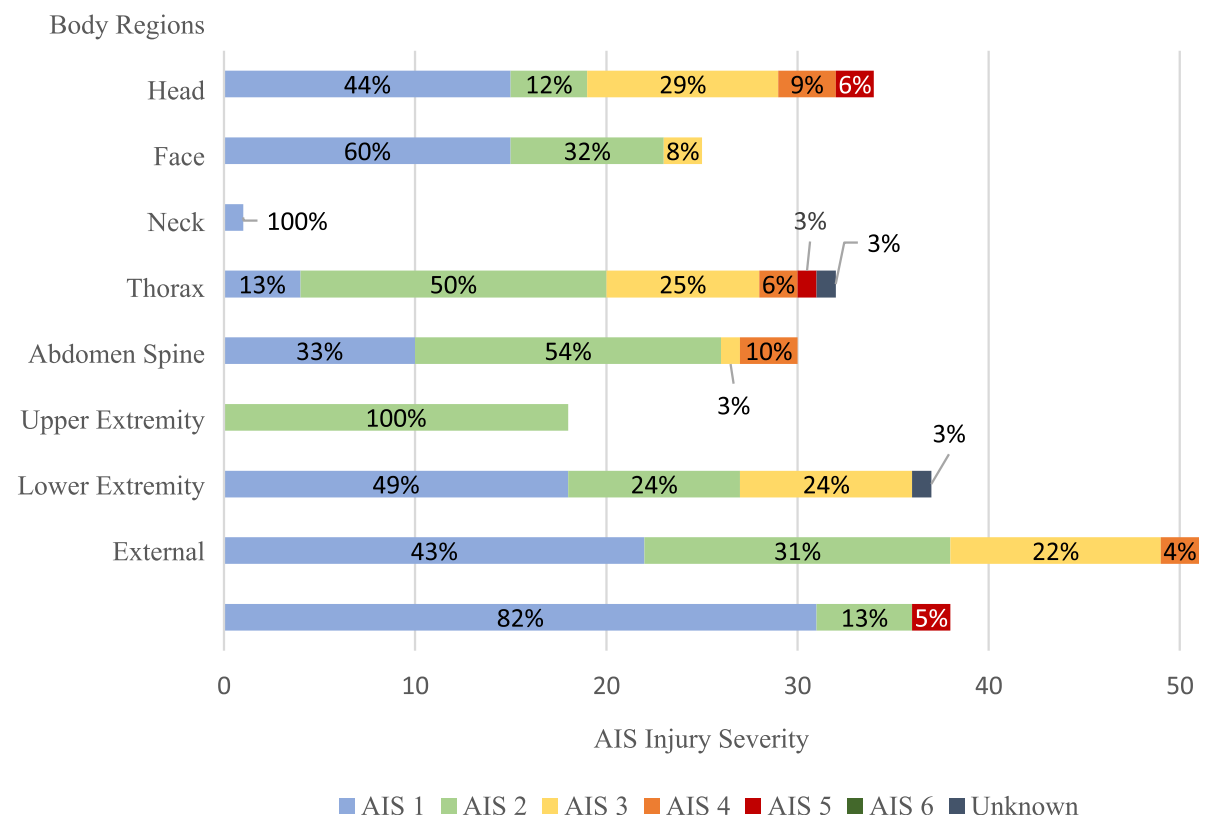

Fig. 2 Proportions of Injuries among French Service Members Treated in US Military Treatment Facilities per Body Region and AIS Severity. AIS Abbreviated Injury Scale 
Table 3 Counts of Surgical Procedures Performed on French Service Members Treated in US Military Medical Treatment Facilities per Level of Care

\begin{tabular}{|c|c|c|c|c|}
\hline Procedures & $\begin{array}{l}\text { Role } 2 \\
n=19(11 \%)\end{array}$ & $\begin{array}{l}\text { Role } 3 \\
n=143(83 \%)\end{array}$ & $\begin{array}{l}\text { Role } 4 \\
n=11(6 \%)\end{array}$ & $\begin{array}{l}\text { Total } \\
n=173\end{array}$ \\
\hline Head (Neurosurgery) & - & $4(2.8 \%)$ & - & $4(2.3 \%)$ \\
\hline Face & - & $10(7.0 \%)$ & - & $10(5.8 \%)$ \\
\hline Eye & - & $9(6.3 \%)$ & - & $9(5.2 \%)$ \\
\hline Dental Procedure & - & $1(0.7 \%)$ & - & $1(0.6 \%)$ \\
\hline Thorax & - & $15(10.5 \%)$ & - & $15(8.7 \%)$ \\
\hline Chest Tube & - & 7 (4.9\%) & - & $7(4.0 \%)$ \\
\hline Emergency Resuscitative Thoracotomy & - & $5(3.5 \%)$ & - & $5(2.9 \%)$ \\
\hline Explorative Thoracotomy & - & $1(0.7 \%)$ & - & $1(0.6 \%)$ \\
\hline Lung Resection & - & $1(0.7 \%)$ & - & $1(0.6 \%)$ \\
\hline Diaphragm Suture & - & $1(0.7 \%)$ & - & $1(0.6 \%)$ \\
\hline Abdomen & $2(10.5 \%)$ & $22(15.4 \%)$ & $5(45.5 \%)$ & $29(16.7 \%)$ \\
\hline Laparotomy & $1(5.3 \%)$ & $6(4.2 \%)$ & $2(18.2 \%)$ & $9(5.2 \%)$ \\
\hline Laparoscopy & - & $2(1.4 \%)$ & - & $2(1.1 \%)$ \\
\hline Bowel & $1(5.3 \%)$ & $6(4.2 \%)$ & $1(9.1 \%)$ & $8(4.6 \%)$ \\
\hline Liver & - & $1(0.7 \%)$ & - & $1(0.6 \%)$ \\
\hline Splenectomy & - & $1(0.7 \%)$ & - & $1(0.6 \%)$ \\
\hline Urological Surgery & - & $4(2.8 \%)$ & - & $4(2.3 \%)$ \\
\hline Other & - & $2(1.4 \%)$ & $2(18.2 \%)$ & $4(2.3 \%)$ \\
\hline Orthopedics & $9(47.4 \%)$ & $23(16.1 \%)$ & $2(18.2 \%)$ & $34(19.7 \%)$ \\
\hline Amputation & $1(5.3 \%)$ & $5(3.5 \%)$ & - & $6(3.5 \%)$ \\
\hline Arthroscopy & - & $1(0.7 \%)$ & - & $1(0.6 \%)$ \\
\hline External Fixation & $2(10.5 \%)$ & $6(4.2 \%)$ & - & $8(4.6 \%)$ \\
\hline Fasciotomy & - & $6(4.2 \%)$ & $1(9.1 \%)$ & $7(4.1 \%)$ \\
\hline Hand Surgery & $1(5.3 \%)$ & $3(2.1 \%)$ & - & $4(2.3 \%)$ \\
\hline Other & $5(26.3 \%)$ & $2(1.4 \%)$ & $1(9.1 \%)$ & $8(4.6 \%)$ \\
\hline Vascular & $1(5.3 \%)$ & $11(7.7 \%)$ & - & $12(2.9 \%)$ \\
\hline Repair & - & $5(3.5 \%)$ & - & $5(2.9 \%)$ \\
\hline Ligation & $1(5.3 \%)$ & $4(2.8 \%)$ & - & $5(2.9 \%)$ \\
\hline Shunt or Bypass & - & $2(1.4 \%)$ & - & $2(1.1 \%)$ \\
\hline Soft tissue (Debridement, Suture, Dressing) & $7(36.8 \%)$ & $58(40.5 \%)$ & $4(36.3 \%)$ & 69 (39.9\%) \\
\hline
\end{tabular}

coalition deploys armed forces. France is one of the main contributors to NATO in these conflicts and has suffered its share of casualties. In this study, we examined the 59 French SMs who were, at one point, treated in Roles 2, 3, or 4 US MTFs. The exclusive distribution of French casualties in the DoDTR in Afghanistan until 2014 and in the Middle East (Iraq and Syria) beginning in 2015 corresponds to the periods when France took part in the conflicts in these countries. The French casualties recorded in the DoDTR in Afghanistan reached a peak in 2009, with 15 battle-related casualties treated in US MTFs that year. However, starting in 2010, we observed a decrease of French casualties in the DoDTR, despite a reported increase in fatalities by the French
Joint Staff (Etat-Major des Armées) [16] over the same period in Afghanistan. This antithetical decline may be attributable to the opening of a French Role 3 MTF in Kabul International Airport (KaIA), which took place in July 2009 in the capital region of Afghanistan; this is where the main body of the French troops was deployed at that time $[3,4]$. Therefore, the majority of French casualties were treated in this French facility. However, the decline in the number of French SMs treated in US MTFs could be due to other reasons, such as changes in operational tempo.

BIs tend to be more severe and predominantly penetrating in nature, and the main mechanism of injury was explosions. The patients in this group were on average 6 
Table 4 Counts and Percentages of French Service Members Receiving IV Fluids and Blood Products per Battle Status. Counts and Ranges (Lowest and Highest) of IV Fluids (in Liters) and Blood Products (in Units) are Provided

\begin{tabular}{|c|c|c|c|c|}
\hline Blood Products and Solutions & Battle $n=46(78 \%)$ & Nonbattle $n=13(22 \%)$ & Total $n=59$ & $p$-value \\
\hline \multicolumn{5}{|l|}{ IV Fluids } \\
\hline Crystalloid recipients & $22(47.8 \%)$ & $4(30.8 \%)$ & $26(44.1 \%)$ & 0.35 \\
\hline Crystalloid units & $99.4(0.35-13.6)$ & $4.2(0.5-1.9)$ & $103.6(0.35-13.6)$ & \\
\hline Colloid recipients & $4(8.7 \%)$ & - & $4(6.8 \%)$ & 0.56 \\
\hline Colloid units & $3(0.25-1.75)$ & - & $3(0.25-1.8)$ & \\
\hline Total recipients & $22(47.8 \%)$ & $4(30.8 \%)$ & $26(44.1 \%)$ & 0.35 \\
\hline Total units & $102.4(0.35-15.3)$ & $4.2(0.5-1.9)$ & $106.6(0.35-15.3)$ & \\
\hline \multicolumn{5}{|l|}{ Blood Products } \\
\hline Whole Blood recipients & $1(2.2 \%)$ & - & $1(1.7 \%)$ & 1.00 \\
\hline Whole Blood units & 4 & - & 4 & \\
\hline $\mathrm{PRBC}^{\mathrm{a}}$ recipients & $11(23.9 \%)$ & $1(7.7 \%)$ & $12(20.3 \%)$ & 0.27 \\
\hline PRBC units & $121(4-30)$ & 7 & $128(4-30)$ & \\
\hline Platelets recipients & $6(13 \%)$ & - & $6(10.2 \%)$ & 0.32 \\
\hline Platelets units & $17(1-6)$ & - & $17(1-6)$ & \\
\hline Cryoprecipitate recipients & $5(10.9 \%)$ & - & $5(8.5 \%)$ & 0.58 \\
\hline Cryoprecipitate units & $86(1-40)$ & - & $86(1-40)$ & \\
\hline FFP ${ }^{\mathrm{b}}$ recipients & $12(26.1 \%)$ & $1(7.7 \%)$ & $13(22 \%)$ & 0.26 \\
\hline FFP units & $111(3-23)$ & 4 & $115(3-23)$ & \\
\hline Total recipients & $13(28.3 \%)$ & $1(7.7 \%)$ & $14(23.7 \%)$ & 0.16 \\
\hline Total units & $339(4-73)$ & 11 & $350(4-73)$ & \\
\hline
\end{tabular}

PRBC Packed Red Blood Cell, FFP Fresh Frozen Plasma

years younger compared to their counterparts with NBIs, probably due to the fact that SMs directly involved in the fights are usually younger, whereas those with higher ranks and in command positions are usually older. Meanwhile, NBIs tend to be blunt in nature, with motor vehicle crash being the most common mechanism of injury. Extremities were the most affected body region, especially in BIs where these injuries account for half of the casualties. However, head injuries were the most severe, followed by thorax injuries. The aforementioned demographic findings are consistent with previous studies [1, 13, 17-19].

Prehospital transportation time was found to be relatively long, exceeding the timeframe for the "golden hour"; however, these data were poorly recorded (only 42.4\% were available). The NATO doctrine of medical support to operations recommends a timeline of one hour for damage control resuscitation and one to two hours for damage control surgery [20, 21]. However, decreasing transportation time in accordance with the "golden hour" principle has been shown to be significantly associated with reduced mortality among US casualties since the US mandate in 2009 [22]. BIs required more surgical procedures, intravenous fluids (IV), and blood products. Most of the procedures performed were in Role 3 US MTFs, given their advanced surgical capabilities compared to
Role 2 MTFs [23, 24]. Similar to the findings in other studies, a large proportion of casualties went directly from point of injury to Role 3 [9]. Orthopedic and soft tissue represented $60 \%$ of all procedures, consistent with previous findings [25]. This emphasizes the need for orthopedic surgeons in deployed MTFs [18]. Nearly all intravenous fluids and blood products were given to patients with BIs. It is worth mentioning that US MTFs do not use freeze-dried plasma, which has been a staple of French combat casualty care [26].

We encountered a number of limitations in this study. Primarily, this study is retrospective, and the patient population studied was small and may not be representative of all French SMs injured in Afghanistan and the Middle East. The SMs in the study may have different characteristics than those treated in French MTFs, or those who were treated in other NATO MTFs. No data has been collected on the reasons why these SMs were brought to US MTFs to be treated, nor is there data available regarding the geographic locations of the injuries, especially in the time period between 2009 and 2013 when KaIA was an operating French MTF. The DoDTR is not designed to collect such information, making it difficult to make inferences based on physical proximity in regard to their admissions to US MTFs. However, "mass casualty" events may require evacuating wounded 


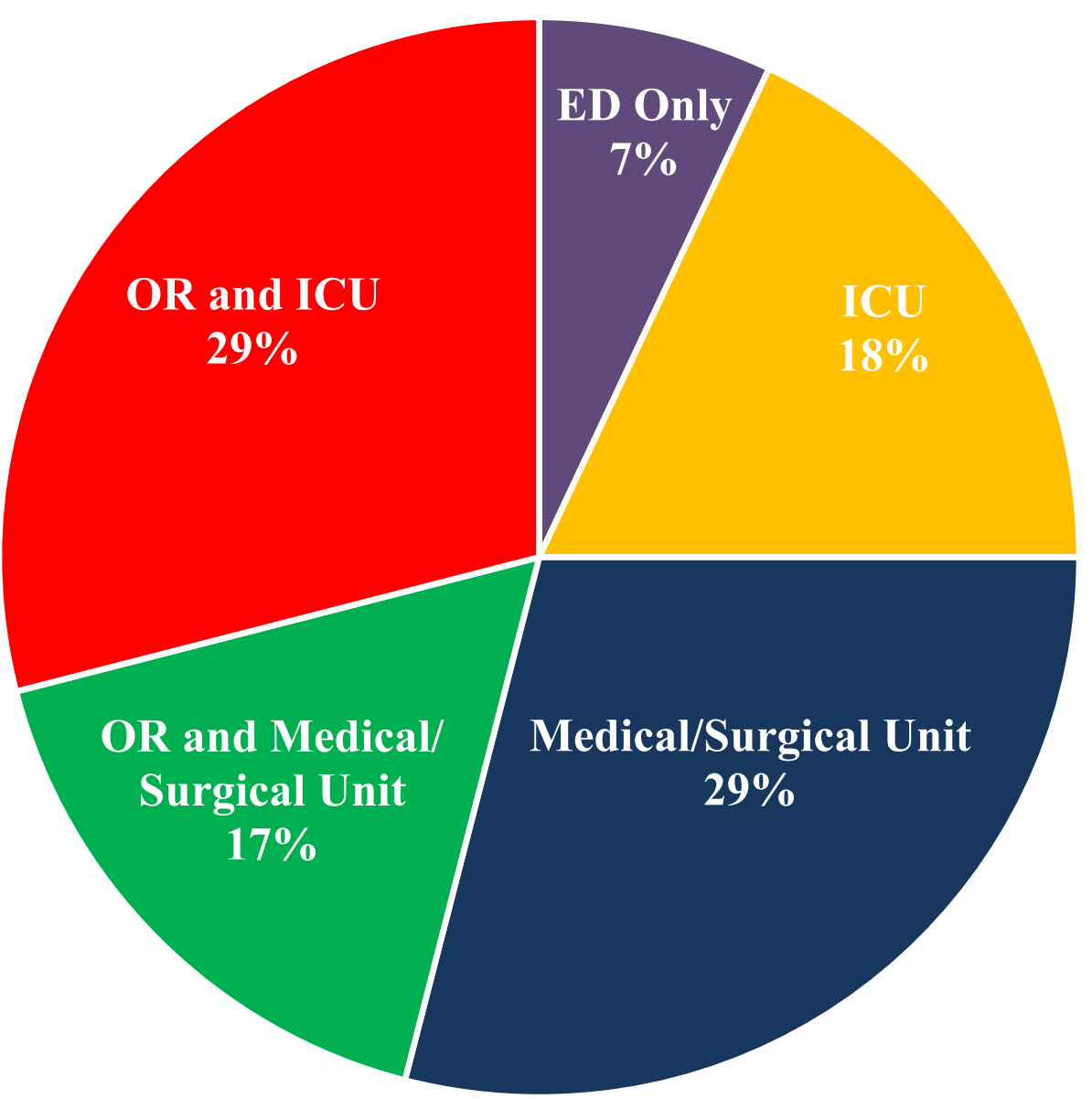

Fig. 3 Post Emergency Department Destination of French Service Members Treated in US Military Treatment Facilities. ED Emergency Department, OR Operation Room, ICU Intensive Care Unit, ED Only: Returned to Duty, Died, or Transferred to Another Facility

soldiers to several MTFs. For example, in January 2012, both French and US Role 3 MTFs received casualties from a massive shooting attack on a French operational base [27]. Therefore, we can expect that the geographic vicinity of the US MTFs to the point of injury, along with bed availability and other logistic reasons are possible explanations. Like other registries, the DoDTR also suffers from missing data. The data are abstracted from medical records and depend on the accuracy of the recorded information by deployed healthcare professionals.
Prehospital data are the most difficult to document and capture [28].

Nevertheless, this study provides a descriptive summary of a population not previously studied. Although not necessarily representative of all injured French soldiers during the same period, the pattern of injuries in this population is valuable information. There are many studies that have been conducted concerning US SMs treated in US MTFs and French SMs treated in French MTFs, but, to our knowledge, there are no studies that

Table 5 Discharge Status of French Service Members Treated in US Military Treatment Facilities per Discharging Level of Care

\begin{tabular}{lllll}
\hline Discharge Status & From Role $2 n=4(6.8 \%)$ & From Role $3 n=46(78.0 \%)$ & From Role $4 n=9(15.25 \%)$ & Total $n=59$ \\
\hline Transferred to US MTF & - & $9(19.6 \%)$ & - & $9(15.2 \%)$ \\
Transferred to French MTF & $3(75.0 \%)$ & $15(32.6 \%)$ & - & $22(37.3 \%)$ \\
Transferred to Local MTF & - & $4(8.7 \%)$ & $4(44.4 \%)$ & $4(6.8 \%)$ \\
Returned to Duty & $1(25.0 \%)$ & $14(30.4 \%)$ & - & $19(32.2 \%)$ \\
Discharged to Home $^{\text {Death }}{ }^{\text {a }}$ & - & $1(2.2 \%)$ & $1(11.2 \%)$ & $1(1.7 \%)$ \\
\hline
\end{tabular}

a.Death after Admission to US Military Treatment Facilities 
aim to examine French SMs treated in US MTFs. This missing information in the care provided to French SMs can, in the future, be combined with their French medical records (if available) in order to provide a complete picture of their injuries, the care provided to them, and their overall outcomes and complications. This study reflects the multinational nature of the medical support now being part of modern operations, where the responsibility of military medical support is increasingly shared by allied nations [29]. Data collection in military operations continues to be a challenge, and the DoDTR represents the largest military trauma data source of its kind. France is currently working on creating a similar military trauma registry in order to collect accurate data on its injured soldiers at deployed French MTFs in order to support on-going performance improvement and injury prevention efforts in combat casualty care. The DoDTR, with its extensive data on traumatic injuries and care provided, offers a compelling model from which the French Military can benefit in building a trauma registry to provide the best possible care to French SMs.

\section{Conclusions}

The majority of injuries sustained by French SMs derived from of battle-related explosive causes and exhibited a predominance of extremities injuries patterns similar to those in combat zones reported by other NATO nations. The DoDTR provides extensive data on traumatic injuries and the care provided in US MTFs, which can be used to inform injury prevention and to improve combat casualty care. This emphasizes the need to establish a French Military trauma registry similar to the DoDTR to record traumatic injuries sustained by French SMs and that is collected by deployed French MTFs to allow performance improvement measures and improve combat casualty care.

\section{Abbreviations}

Bl: Battle Injury; DoDTR: Department of Defense Trauma Registry; IV: Intravenous; JTS: Joint Trauma System; MTF: Military Treatment Facility; NATO: North Atlantic Treaty Organization; NBI: Nonbattle Injury; SM: Service Member; US: United States

\section{Acknowledgments}

None.

\section{Funding}

None.

\section{Availability of data and materials}

The data that support the findings of this study are available from the Department of Defense Joint Trauma System but restrictions apply to the availability of these data. They are not publicly available and are only available upon reasonable request and with permission of the Joint Trauma System.

\section{Disclaimer}

The views expressed herein are those of the authors and do not reflect the official policy or position of the US Department of Defense Joint Trauma System or the French Ministry of the Armed Forces.

\section{Authors' contributions}

MS conducted the analyses and was the main writer of the manuscript. TM is the $\mathrm{PI}$ and participated in the analyses and the interpretation of the findings. $J J$ and ZS reviewed the manuscript and assisted in its final version. All authors read and approved the final manuscript.

\section{Ethics approval and consent to participate}

This quality improvement project was deemed exempt from institutional board review by the US Army Institute of Surgical Research because it was not designed to contribute to generalizable knowledge; therefore, it does not constitute research as defined in 32 CFR 219.102(d).

\section{Consent for publication}

Not Applicable.

\section{Competing interests}

The authors declare that they have no competing interests.

\section{Author details}

${ }^{1}$ United States Department of Defense Joint Trauma System, Joint Base San Antonio Fort Sam Houston, Houston, TX 78234, USA. ${ }^{2}$ Naval Medical Readiness Training Command Jacksonville, Jacksonville, FL 32212, USA. ${ }^{3}$ Sainte Anne Military Hospital, 600-83800 Toulon Cedex 9, BP, France.

Received: 30 October 2018 Accepted: 19 February 2019

Published online: 27 February 2019

\section{References}

1. Shen-Gunther J, Ellison R, Kuhens C, Roach CJ, Jarrard S. Operation enduring freedom: trends in combat casualty care by forward surgical teams deployed to Afghanistan. Mil Med. 2011;176(1):67-78.

2. Beekley AC, Watts DM. Combat trauma experience with the United States Army 102nd forward surgical team in Afghanistan. Am J Surg. 2004;187(5):652-4.

3. Barbier O, Malgras B, Versier G, Pons F, Rigal S, Ollat D. French surgical experience in the role 3 medical treatment facility of KalA (Kabul international airport, Afghanistan): the place of the orthopedic surgery. Orthop Traumatol Surg Res. 2014:100(6):681-5.

4. Brondex A, Viant E, Trendel D, Puidupin M. Medical activity in the conventional hospitalization unit in Kabul NATO role 3 hospital: a 3-monthlong experience. Mil Med. 2014;179(2):197-202.

5. Bonnet S, Gonzalez F, Poichotte A, Duverger V, Pons F. Lessons learned from the experience of visceral military surgeons in the French role 3 medical treatment Facility of Kabul (Afghanistan): an extended skill mix required. Injury. 2012:43(8):1301-6.

6. Aoun O, Roqueplo C, Rapp C. Spectrum and impact of health problems during deployment: a prospective, multicenter study of French soldiers operating in Afghanistan, Lebanon and cote d'Ivoire. Travel Med Infect Dis. 2014;12(4):378-84

7. Service de Santé des Armées. https://www.defense.gouv.fr/sante/. Accessed 18 June 2018.

8. Malgras B, Barbier O, Petit L, Rigal S, Pons F, Pasquier P. Surgical challenges in a new theater of modern warfare: the French role 2 in Gao. Mali Injury. 2016:47(1):99-103.

9. de Lesquen $\mathrm{H}$, Beranger $\mathrm{F}$, Berbis J, et al. Challenges in war-related thoracic injury faced by French military surgeons in Afghanistan (2009-2013). Injury. 2016;47(9):1939-44.

10. Beranger $\mathrm{F}$, Lesquen $\mathrm{H}$, Aoun $\mathrm{O}$, et al. Management of war-related vascular wounds in French role 3 hospital during the afghan campaign. Injury. 2017:48(9):1906-10.

11. Barbier $O$, Pasquier $P$, Racle $M$, Baudoin $Y$, Malgras B. Dynamic insights on surgical activity in a new modern warfare: the French role 2 in Bangui. Central African Republic Mil Med. 2017;182(3):e1756-61.

12. Bailey, J., Spott, M. A., Costanzo, G. P., Dunne, J.R., Dorlac, W., Eastridge, B. Joint Trauma System: Development, Conceptual Framework, and Optimal Elements, U.S. Department of Defense, U.S. Army Institute for Surgical Research, 2012

13. Owens BD, Kragh JF Jr, Wenke JC, Macaitis J, Wade CE, Holcomb JB. Combat wounds in operation Iraqi freedom and operation enduring freedom. J Trauma. 2008;64(2):295-9.

14. United States Department of Defense. Joint Trauma System Center of Excellence for Trauma. https://jts.amedd.army.mil/. Accessed 18 June 2018. 
15. Gennarelli TA, Wodzin E. Abbreviated injury scale 2005: update 2008 Russ Reeder; 200.

16. Etat-Major des Armées: Opération Pamir. https://www.defense.gouv.fr/ operations/operations/autres-operations/operations-achevees/operationpamir-2001-2014/. Accessed 18 June 2018.

17. Mathieu L, Bertani A, Gaillard C, Ollat D, Rigal S, Rongieras F. Wartime upper extremity injuries: experience from the Kabul international airport combat support hospital. Chir Main. 2014;33(3):183-8.

18. Hoencamp R, Vermetten E, Tan EC, Putter H, Leenen LP, Hamming JF. Systematic review of the prevalence and characteristics of battle casualties from NATO coalition forces in Iraq and Afghanistan. Injury. 2014;45(7):1028-34.

19. Cai YL, Ju JT, Liu WB, Zhang J. Military trauma and surgical procedures in conflict area: a review for the utilization of forward surgical team. Mil Med. 2018;183(3-4):e97-106.

20. NATO Standardization Agency. AD 83-1: ACO Directive on Medical Support to Operations. 2 ed: North Atlantic Treaty Organization (NATO); 2009. Available at http://ids.nic.in/UK\%20Doctrine/UK\%20(12).pdf; Accessed 18 June 2018.

21. North Atlantic Treaty Organization. NATO Logistics Handbook Chapter 16: Medical support. https://www.nato.int/docu/logi-en/1997/lo-1610.htm. Accessed 18 June 2018.

22. Kotwal RS, Howard JT, Orman JA, et al. The effect of a Golden hour policy on the morbidity and mortality of combat casualties. JAMA Surg. 2016; 151(1):15-24.

23. Brisebois CR, Hennecke MP, Kao CNR, et al. The Role 3 multinational medical unit at kandahar Airfield 2005-2010. Can J Surg. 2011;54(6):S124.

24. Van Dongen $\Pi T$, Idenburg FJ, Tan EC, et al. Combat related vascular injuries: Dutch experiences from a role 2 MTF in Afghanistan. Injury. 2016;47(1):94-8.

25. Turner CA, Stockinger ZT, Gurney JM. Combat surgical workload in operation Iraqi freedom and operation enduring freedom: the definitive analysis. J Trauma and AC Surg. 2017;83(1):77-83.

26. Martinaud C, Ausset S, Deshayes AV, Cauet A, Demazeau N, Sailliol A. Use of freeze-dried plasma in French intensive care unit in Afghanistan. J Trauma. 2011:71(6):1761-4.

27. Planchet M, Delbart C, Thomas A, Chenais L, Cazes N, Puidupin A. Prise en charge d'un afflux saturant de blessés de guerre français en Afghanistan. Méd Armées. 2013;41(2):175-82.

28. Robinson JB, Smith MP, Gross KR, et al. Battlefield documentation of tactical combat casualty care in Afghanistan. US Army Med Dep J. 2016; (2-16): 87-95.

29. Tien CH, Beckett MA, Garraway LN, Talbot LM, Pannell CD, Alabbasi T.

Advances in damage control resuscitation and surgery: implications on the organization of future military field forces. Can J Surg. 2015;58(3):S91.

Ready to submit your research? Choose BMC and benefit from:

- fast, convenient online submission

- thorough peer review by experienced researchers in your field

- rapid publication on acceptance

- support for research data, including large and complex data types

- gold Open Access which fosters wider collaboration and increased citations

- maximum visibility for your research: over $100 \mathrm{M}$ website views per year

At $\mathrm{BMC}$, research is always in progress.

Learn more biomedcentral.com/submissions 